\title{
Influence of Nitrogen Fertilizer on Seedling Production of CUPUAÇUZEIRO (Theobroma grandiflorum Schum.)
}

\author{
Renata Aparecida Cardoso Campos, Ivio Alves Milhomem, Susana Cristine Siebeneichler, \\ Magno De Oliveira, Laina Pires Rosa, Raffael Batista Marques, Gustavo Henrique Germendorff
}

\begin{abstract}
The Cupuaçuzeiro (Theobroma grandiflorum Schum.) is widely cultivated in tropical regions of Brazil but has a few recommendations and requirements. The quality and growth of seedlings can be improved by nitrogen fertilization. The objective of this work was to evaluate the influence of different dosages of urea applied and coverage in the substrate for the seedling production of the Cupuaçu tree. The experiment was installed in the University campus of Gurupi from Universidade Federal the Tocantins in the first half of 2010. The experimental design used was the random blocks with four repetitions and five treatments, being $0,20,40,60$ e $80 \mathrm{mg}$ dm-3 the basis of urea nitrogen. Each parcel consisted of five seedlings queued. Were measured weekly the diameter and height of the aerial part. The $72 \mathrm{DAE}$, the seedlings were collected for the evaluation of the following biometric data: average leaf area (cm2), average leaf area, and total and total (g), the relationship APA/DC, APA/ MSPA and the Dickson quality index (IQD). The results were subjected to polynomial regression analysis to evaluate the effects of doses of nitrogen, testing the linear and quadratic models. The relation and height of the aerial part by the diameter of the stem and height of the aerial part by the dry mass of the aerial part showed that fertilizations between 74 and $80 \mathrm{mg} . d \mathrm{~m}-3$ of $\mathrm{N}$ should provide Cupuaçu seedlings more balanced. The IQD indicated that doses of $66 \mathrm{mg.dm}-3$ of $\mathrm{N}$ may promote a better quality standard of Cupuaçu tree seedlings.
\end{abstract}

Index Terms - Theobroma grandiflorum, fruit growing, IQD.

\section{INTRODUCTION}

The Cupuaçu tree (Theobroma grandiflorum Schum.) is a fruit tree widely cultivated in the tropical regions of Brazil and also found in nature, in its natural habitat in the soil firm forests of the Amazon region, mainly in the State of Pará. It belongs to the family Malvacea and is considered one of the

*Renata Aparecida Cardoso Campos, Laboratory of plant ecophysiology, Federal University of Tocantins, Federal University of Tocantins - Brazil

Ivio Alves Milhomem, Laboratory of plant ecophysiology, Federal University of Tocantins, Federal University of Tocantins - Brazil;

Susana Cristine Siebeneichler, Laboratory of plant ecophysiology, Federal University of Tocantins, Federal University of Tocantins - Brazil;

Magno De Oliveira, Laboratory of plant ecophysiology, Federal University of Tocantins, Federal University of Tocantins - Brazil

Laina Pires Rosa, Laboratory of plant ecophysiology, Federal University of Tocantins, Federal University of Tocantins - Brazil;

Raffael Batista Marques, Laboratory of plant ecophysiology, Federal University of Tocantins, Federal University of Tocantins - Brazil;

Gustavo Henrique Germendorff, Federal University of Tocantins, Federal University of Tocantins - Brazil. most attractive fruit trees of the Amazon region, because it has a pulp of flavor and aroma appreciated, being used in the manufacture of various products such as juices, jellies, liqueurs, compotes, creams, sweets, ice creams, among others [1].

With the increase of consumption in the last decades, the cultivation of the Cupuaçu tree has expanded to other Brazilian regions, leaving the extractive exploitation over past, because it is in the process of domestication [2] [3].

In the commercial plant of Cupuaçu seedlings propagated sexually or by the vegetative route are used, through the grafting. The Cupuaçu tree presents characteristics of the precocity of fruiting, making the vegetative propagation unnecessary for the reduction of the juvenile period of the plant [4].

Due to being a native species of recently discovered commercial interest, the Cupuaçu tree has few recommendations and prescriptions. Among them are the best conditions of production of seedlings, considering factors such as seed type, substrate, and fertilization.

One of the main factors that guarantee the success of fruit growing is the quality of the seedlings made by the producer. Thus, the first step to success in the implementation of a poem is to obtain quality changes that provide an adaptation in the production of the field, with good condition [5] [6].

Conditions favorable to the production of seedlings contribute to the increase of homogeneity, sanity, and reduction of planting mortality. The production of seedlings is influenced by external factors such as water, light, temperature, oxygen, pathogens, internal seed quality factors and the availability of nutrients.

The quality and growth of the seedlings can be improved through mineral fertilization, with developmental reflexes, precocity and greater survival in the field, so much which without its application it results in problems in the transplant, because it does not reach the ideal parameters [7, 8].

Nitrogen is the mineral nutrient most required by most plants and deficiency of this nutrient usually limits plant productivity in agricultural ecosystems [9] [10].

According to [11] [10], the use of nitrogen to produce seedlings in containers has shown good results in several crops, maximizing its production.

Nitrogen deficiencies initially manifested in the chlorotic Cupuaçu seedlings in the lower leaves and with the increased intensity of the deficiency develop necrotic points on the edge of the sheet, beginning at the apex of the leaf between the 
secondary veins. With the intensification of the deficiency, the chlorosis extends throughout the plant occurring necrosis of the superior leaves [12] [13]. The objective of this work was to evaluate the influence of different dosages of urea applied on the substrate cover for the production of Cupuaçu tree seedlings.

Table 1: Stem diameter and height of the Cupuaçu tree seedlings to air 30 DAE.

\begin{tabular}{lll}
\hline Treatment & Diameter $(\mathrm{mm})$ & Height $(\mathrm{cm})$ \\
\hline T1 - Witness & $4,02 \mathrm{a}$ & $16,72 \mathrm{a}$ \\
\hline $\mathrm{T} 2$ - 20 mg dm-3 & $4,02 \mathrm{a}$ & $16,92 \mathrm{a}$ \\
\hline $\mathrm{T} 3-40 \mathrm{mg} \mathrm{dm}-3$ & $3,92 \mathrm{a}$ & $16,79 \mathrm{a}$ \\
\hline $\mathrm{T} 4-60 \mathrm{mg} \mathrm{dm}-3$ & $3,99 \mathrm{a}$ & $16,83 \mathrm{a}$ \\
\hline $\mathrm{T} 5-80 \mathrm{mg} \mathrm{dm}-3$ & $4,04 \mathrm{a}$ & $16,58 \mathrm{a}$ \\
\hline $\mathrm{CV}(\%)$ & 5,6 & 2,87 \\
\hline
\end{tabular}

Averages compared by Tukey a $5 \%$ of probability.

\section{MATERIALS AND METHODS}

The present work was carried out at the Experimental Station of the University Campus of Gurupi-Tocantins Federal University in the first half of 2010. The experiment was installed under the screen nylon type (50\% of brightness). Polyethylene bags were used to $1,12 \mathrm{dm} 3$, filled with $1 \mathrm{dm} 3$ in Earth-based substrate of the basement and carbonized rice straw in the proportion of $1: 1 \mathrm{v} / \mathrm{v}$, enriched with $2,68 \mathrm{~kg} \mathrm{~m}-3$ of superphosphate.

To obtain the seeds were selected 6 fruits of a commercial Orchard of Tabocuçu Farm, located in the city of Miracema do Tocantins, Tocantins. The fruits were broken, by removing the seeds that were depleted with the aid of scissors, washed for the withdrawal from the rest of the mucilage and, then, with the aid of a soft and absorbent, It was removed the excess water. After 24 hours were sown seeds 198 , only one in every sachet, taking advantage to make the experiment only those germinated on a regular basis and who had equity in stem diameter and height, ranging from 3,92 a 4,04 e 16,58 a 16,92 respectively.

The experimental design used was the random blocks with four repetitions and five treatments, being $0,20,40,60$ e 80 $\mathrm{mg} \mathrm{dm}-3$ the basis of urea nitrogen, applied weekly in liquid form, using $8 \mathrm{ml}$ of the solution per plant. Each parcel consisted of five seedlings queued, being used to obtain the data, the three sets that are located inside of the parcels.

Fertilization started at 30 days after plant emergence, as well as the height of the assessment (APA) and stem diameter (DC), which were carried out weekly, totaling at the end of the experiment, set 6 and 7 data collections. The diameter of the stem was obtained with the aid of digital caliper, by taking two measurements perpendicular to each other and the $0.5 \mathrm{~cm}$ above the cotyledons, and main stem height, measured with a ruler.

The 72 DAE, the seedlings were collected for evaluation of the following biometric data: average leaf area $(\mathrm{cm} 2)$ by leaf area meter, model CI 202 - CID Incorp; and root dry mass (MSR) and shoot (MSPA) and total (MST), so that the samples were dried in an oven with forced air circulation the $70{ }^{\circ} \mathrm{C}$ until constant weight, and subsequently in heavy scales semi-analytical.

With these variables were calculated against APA, APA/MSPA and the Dickson quality index (IQD). The IQD, second [14], is calculated in a way that is balanced, including the relationship of morphological parameters as MST (sum of MSPA with MSR), MSPA and MSR, APA and DC which features the following formula: $I Q D=M S T(\mathrm{~g}) /[A P A(\mathrm{~cm})$ $/ D C(m m)+M S P A(g) / M S R(g)]$.

The results were subjected to polynomial regression analysis to evaluate the effects of doses of nitrogen, testing the linear and quadratic models, being selected to explain the results, which present the biggest value for the coefficient of determination (R2). The analyses were carried out with the aid of the program EXCEL, 2003.

\section{RESULTS AND DISCUSSION}

It can be observed that there was a linear response in the evolution of the height of the Cupuaçu tree seedlings in due time after the start of nitrogenous fertilization (Figure 1). Treatments that showed the greatest height growth were those in which the seedlings underwent the largest doses of nitrogen, 80, 60 e $40 \mathrm{mg} . \mathrm{dm}-3$, indicating the positive effect of nitrogen fertilization on the growth of the seedlings.

Among the treatments, which provided greater height increment was $60 \mathrm{mg} . \mathrm{dm}-3 \mathrm{~N}$ with $5,84 \mathrm{~cm}$, followed by the $80 \mathrm{mg} . \mathrm{dm}-3$ with $5,38 \mathrm{~cm}$ e $40 \mathrm{mg} \cdot \mathrm{dm}-3$ with $5,34 \mathrm{~cm}$. Plants that received $20 \mathrm{mg} . \mathrm{dm}-3 \mathrm{~N}$ are ineffective against the other, previously cited doses, providing an increase in height of only 4,09 cm. However, it proved better than the witness, which showed a growth of $2,74 \mathrm{~cm}$ in the course of the evaluation period.

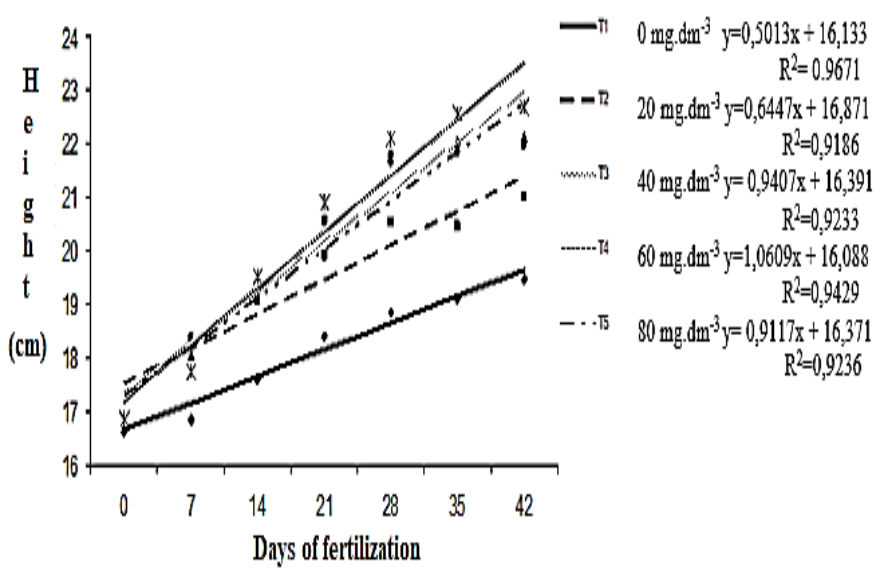

Fig. 1: The height of the aerial part of the Cupuaçu tree seedlings in relation to nitrogen doses depending on the days after the initiation of the nitrogenous fertilization. UFT, Gurupi-TO, 2010.

According to [15] and [10] working with nitrogen fertilization in the formation of rootstocks in the absence of mineral supplementation with nitrogen, plant growth, which 
feature performance quite lower than those fertilized with a nutrient source. [16], found the gain in height of seedlings of Umbuzeiro up 156\% When compared plants fertilized with $\mathrm{N}$, where the seedlings have issued few branches and often demonstrating gems still numb. According to him, these results demonstrate the participation of this nutrient in the Constitution of essential proteins in plant growth resulting in inhibition of the cell division process.

Figure 2 shows the quadratic regression analysis of the height of the shoot regarding the doses of nitrogen. Segundo [14] and the height of the aerial part is an important biometric data to predict the initial growth in the field, being technically accepted as a good measure of the performance of plantula. Through this analysis, it was found that the maximum estimated value is $22.5 \mathrm{~cm}$, from $59.2 \mathrm{mg}$ dose, dm-3 nitrogen (Figure 2). It is observed that the determination of nitrogen from that caused depressive effects on the height of the aerial part of the plant. Comparing the results obtained by the witness without nitrogen, with the other treatments, there was clearly the importance of the nitrogen supply to the Cupuaçu tree growth. This result agrees with [17], and which found that the absence of nitrogen on the production of rootstalk of Saputizeiro compromises the growth of seedlings, when confronted those who received the nutrient, verified also on work[13].

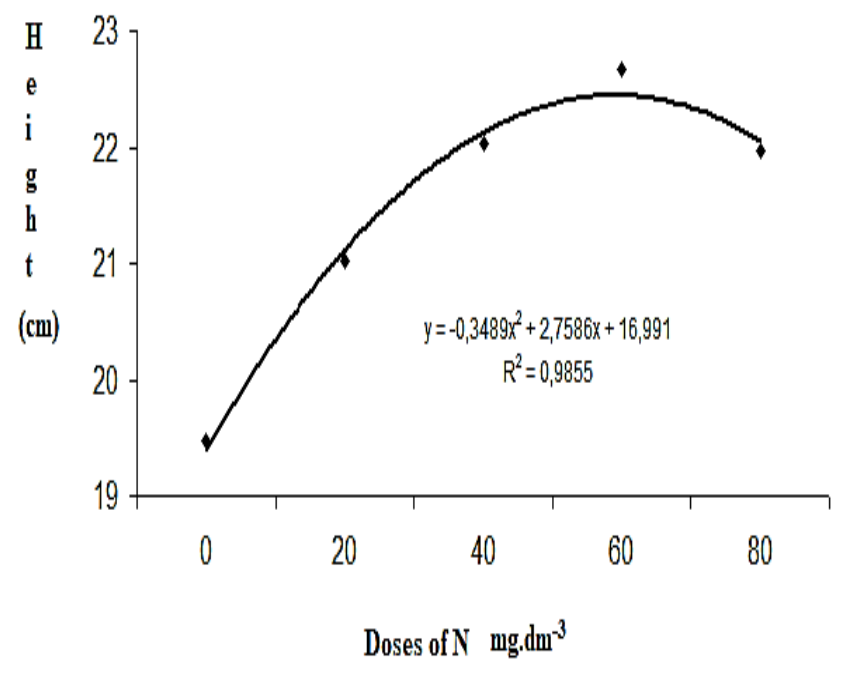

Fig. 2: Height of the aerial part of Cupuaçu tree seedlings, according to the doses of nitrogen to 42 days after the beginning of weekly fertilization. UFT, Gurupi-TO, 2010

According to [18] and [19] the diameter of the stem is easily measurable, whose method is not destructive, being one of the most important parameters to estimate the survival of seedlings in the field.

For all doses applied, the seedlings showed a positive linear response, showing a gradual increase in the diameter of the stem of the Cupuaçu tree seedlings in relation to the time of the experiment. However, with the addition of $\mathrm{N}$, it was observed that the seedlings showed better behavior with respect to this parameter (Figure 3). The treatments with 80 , 60,40 e $20 \mathrm{mg} \cdot \mathrm{dm}-3 \mathrm{~N}$ provided a higher stem diameter, differed from witness after $28^{\circ}$ day after fertilization.

At the end of the evaluation period, the treatments with the doses of 80, 60, 40 e $20 \mathrm{mg} . \mathrm{dm}-\mathrm{N} 3$, provided an increase in diameter of the stem of 1,$14 ; 1,15 ; 1,18$ e $0,94 \mathrm{~mm}$, respectively, while the witness allowed only $0.53 \mathrm{~mm}$ increase in stem diameter.

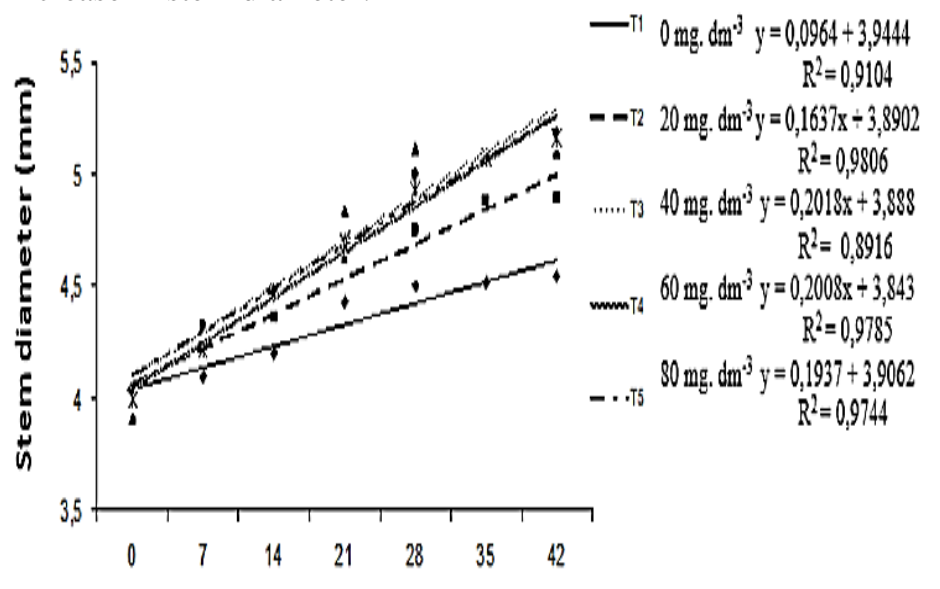

Davs of fertilization

Fig. 3: The diameter of the stem of the Cupuaçu tree seedlings with relative nitrogen doses depending on the days after the start of nitrogenous fertilization. UFT, Gurupi-TO, 2010.

Figure 4 allows us to observe the response of $\mathrm{N}$ in the diameter of the Cupuaçu tree seedlings, the quadratic model was the best in the evolution of the diameter of the seedlings with increased doses of nitrogen $(\mathrm{R} 2=0,969)$. This positive quadratic effect indicates that the use of increasing $\mathrm{N}$ doses resulted in an increase in seedling diameter values, and the estimated dose of $70 \mathrm{mg} \cdot \mathrm{dm}-3$, allowed to reach the maximum value of $5.18 \mathrm{~mm}$. Similar results found [15], in work with lemon tree grafting "Harpsichord", [20], with work rootstalk of Saputizeiro, Lombardi et al. (1999) to experiment with peach rootstocks, cv. Capdeboscq, [21], with clonal seedlings of cocoa and [22] with Acacia seedlings. [23] defined that to change knew, the doses of 124 e 197 mg.dm $-3 \mathrm{~N}$, detected through quadratic models, provide the largest diameters in red-yellow and cambisols argisols, with values of 7,83 e 7,90 mm, respectively.

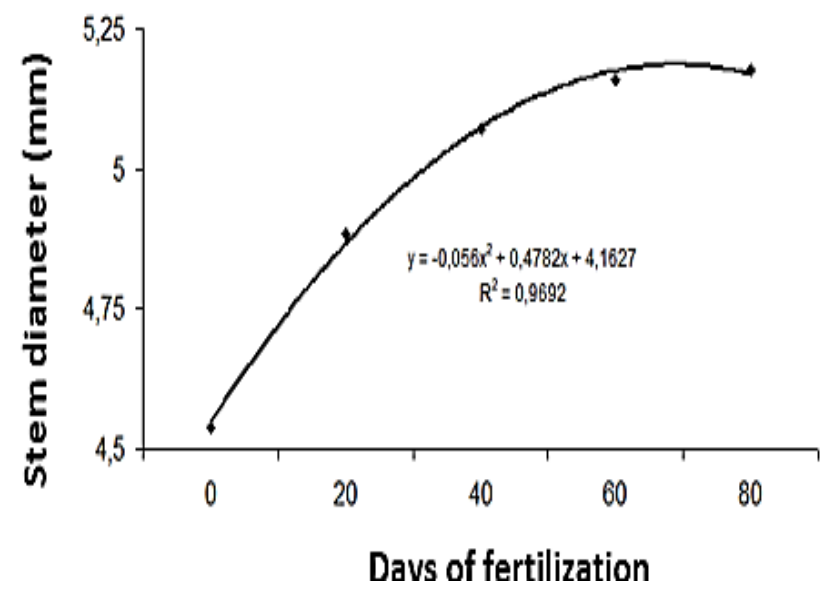


Fig. 4: The diameter of the stem of Cupuaçu tree seedlings, according to the doses of nitrogen to 42 days after the beginning of weekly fertilization. UFT, Gurupi-TO, 2010.

According to [24] and [25] the value resulting from dividing the height of the aerial part of a seedling by its diameter, represents a balance of growth, relationship between these two parameters in a single index.

Second [26] and [27] the relative height/stem diameter is one of the characteristics used to evaluate the quality of forest seedlings because in addition to reflect the accumulation of reserves, better fixation in the soil.

The data obtained from the relative height of the shoot by the diameter of the stem were adjusted by the quadratic model (Figure 5). The maximum value of the relationship turned around 4.35 was obtained in witness. [24] cited by [18] States that the lower the value of the relationship, the greater the ability of seedlings survive and settle on the final planting area. In Figure 5, you can see that the minimum estimated value was found with the dose of mg.dm $-3 \mathrm{~N} \mathrm{80}$, resulting in a relationship APA/DC 4,25 In this way, it should be noted that the fertilization of $80 \mathrm{mg} \cdot \mathrm{dm}-3 \mathrm{~N}$ provides a more balanced and vigorous seedlings.

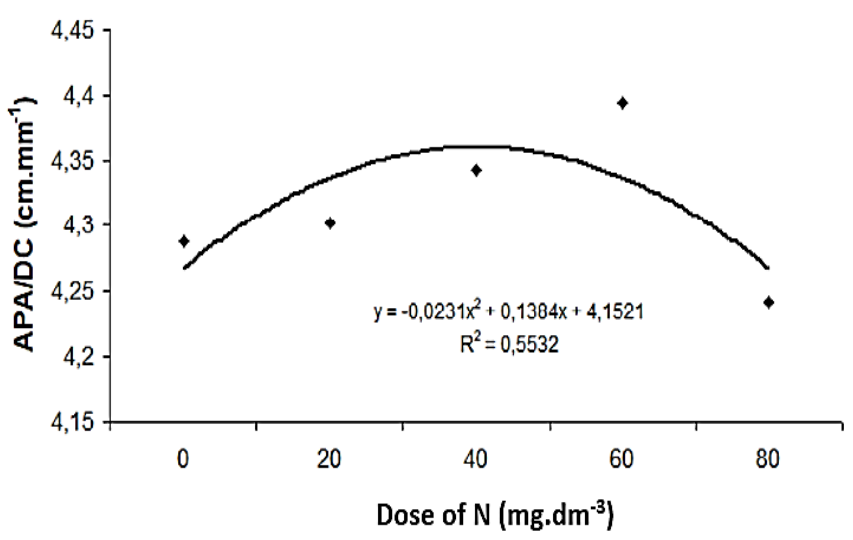

Fig. 5: Aboveground height ratio from the diameter of the stem in Cupuaçu tree seedlings, according to the doses of nitrogen to 42 days after the beginning of weekly fertilization. UFT, Gurupi-TO, 2010.

Analysis of leaf area is important for highlighting the leaves as a source of production of organic sap which has a key role in plant growth [28] cited by [16].

The leaf area showed quadratic response to nitrogen fertilization, reaching the maximum development with the estimated value in $309 \mathrm{~cm} 2$, by the study of regression, in the dose of $80 \mathrm{mg} . \mathrm{dm}-3 \mathrm{~N}$ (Figure 5). A similar response had [21], which found a quadratic effect of nitrogenous fertilization in clonal seedlings of cocoa. [16], verified the nitrogen fertilization has contributed positively to the initial development of seedlings of Umbuzeiro, demonstrated by an increase in leaf area and in other parameters as well as similar results found for [29] in Sunflower.

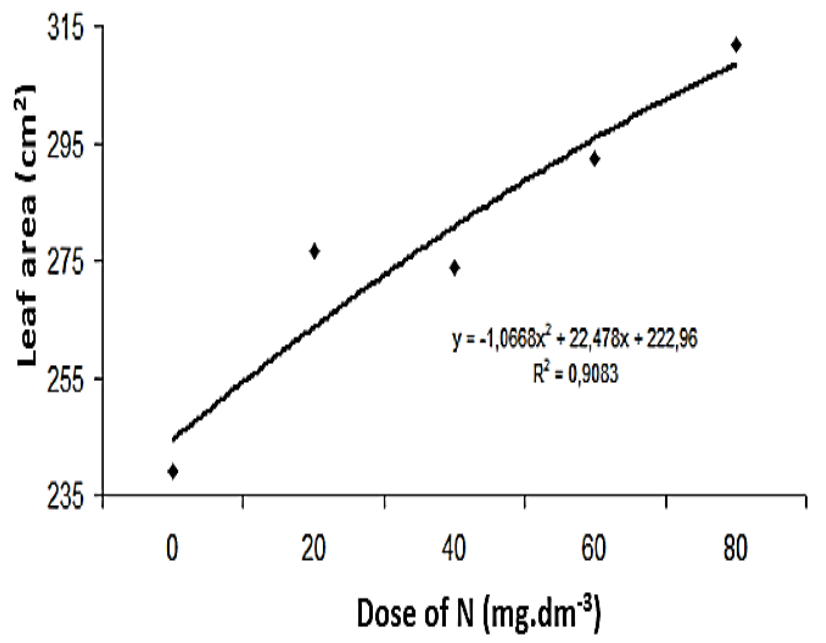

Fig. 6: Leaf area of seedlings of Cupuaçu tree, depending on the nitrogen doses to 42 days after the beginning of weekly fertilization. UFT, Gurupi-TO, 2010

The data obtained from aerial dry mass were adjusted by the quadratic model (Figure 7), from which determined the maximum production $2,36 \mathrm{~g}$, corresponding to the use of the dose of $65,5 \mathrm{mg} \cdot \mathrm{dm}-3$. The comparison of the witness without nitrogen, with the other treatments, demonstrates performance lower than those fertilized with urea, highlighting the importance of providing nitrogen for seedling formation of Cupuaçu aiming to incorporation of organic material; Similar results were found in works with nitrogen fertilization on seedlings of cocoa [21], cultivated plant nearest the Cupuaçu, and in seedlings of sabia [23] where the dose of $186 \mathrm{mg} . \mathrm{dm}-3 \mathrm{~N}$ the basis of ammonium nitrate resulted in the maximum value of $18.2 \mathrm{~g}$ MSPA estimated by quadratic model.

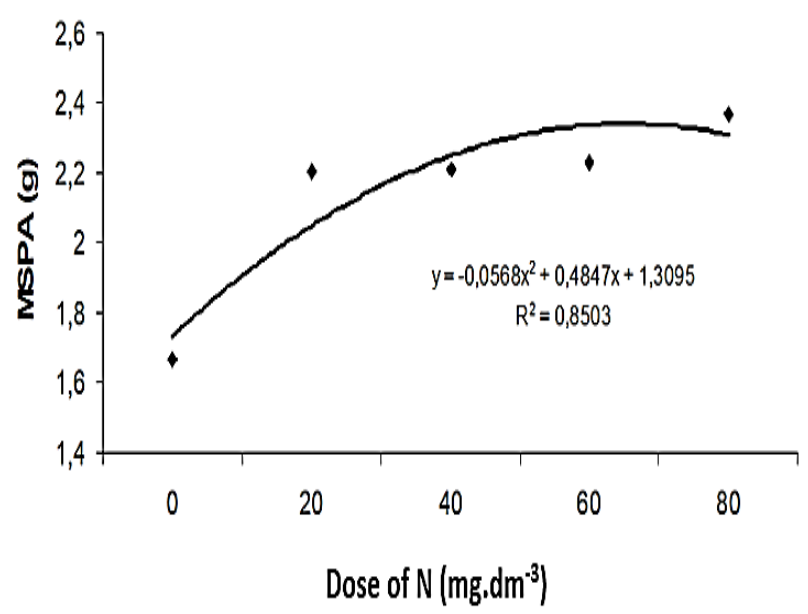

Fig. 7: Aerial dry mass (MSPA) Cupuaçu tree seedlings, according to the doses of nitrogen to 42 days after the beginning of weekly fertilization. UFT, Gurupi-TO, 2010. 
According to [18] and [30] and root dry mass has been recognized by several authors as being one of the most important and best parameters to estimate the survival and initial growth of seedlings in field.

The response of the Cupuaçu tree seedlings to increased nitrogen fertilization followed a quadratic model for root dry mass. A result similar to in [31] with passion fruit seedlings $1,12 \mathrm{~g}$ with the maximum estimated dose in $60 \mathrm{mg} \cdot \mathrm{dm}-3 \mathrm{~N}$ in cover every 7 days on the substrate. After this point, it was observed a mild depressive effect. A similar effect, however, more pronounced was found by [11] with the production of seedlings of sweet passion and [32], with a change in cells of yellow passion. By [33], reports that the depressive effect may be due to the decrease in the $\mathrm{pH}$ of the substrate, and the release of $\mathrm{H}+$ was produced during the process of nitration of urea applied.

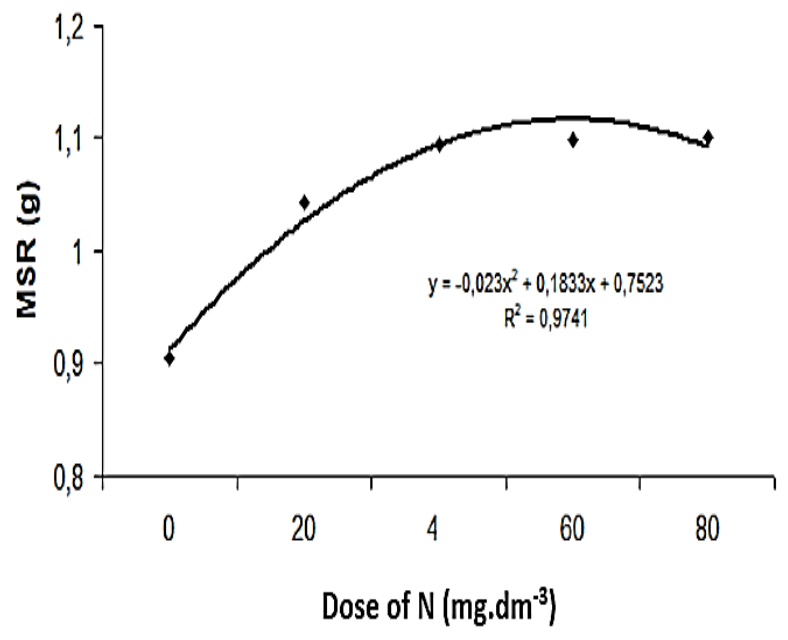

Fig. 8: Root dry mass (MSR) of Cupuaçu tree seedlings, according to the doses of nitrogen to 42days after the beginning of weekly fertilization.

The treatments with the addition of nitrogen urea-based provided a significant effect as the total dry mass. This result may be associated with increased leaf area promoted by the application of nitrogen in seedlings, and the accumulation of matter relies intrinsically on plant photosynthesis, which is in the middle of the production of carbohydrates, lipids, and proteins. In this way, observing a quadratic effect, where the dose of $64 \mathrm{mg} . \mathrm{dm}-3 \mathrm{~N}$ provided the maximum value of 3.44 $\mathrm{g}$ of MST (Figure 9). A similar response to nitrogen fertilization was also found for [23], in the seedling production experiment of thrush. [34], studying the production of potted citrus seedlings, observed that the significant quadratic effect promoted $\mathrm{N}$ production of the seedling dry mass of Valencia orange tree. They found that at a dose of $1,25 \mathrm{~g}$ they found that at a dose of 13, dry mass and maximum production $14,77 \mathrm{~g}$ dry mass was obtained with a dose of $6,02 \mathrm{~g}$ per plant.

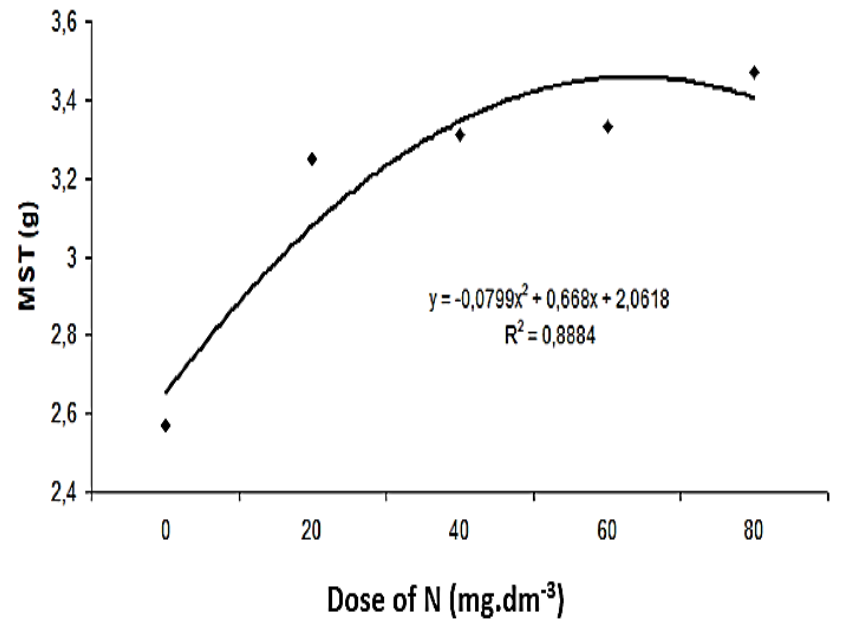

Fig. 9: Total dry mass (MST) Cupuaçu tree seedlings, according to the doses of nitrogen to 42 days after the beginning of weekly fertilization. UFT, Gurupi-TO, 2010.

According to [23], this relationship is not MSPA/APA commonly used, however, it can be of great assistance, to predict the survival potential of the changes in the field.

In Figure 10, allows observing the response of Cupuaçu tree seedlings to nitrogen application in the substrate, observing the quadratic effect, where the dose of $77 \mathrm{mg} . \mathrm{dm}-3$ $\mathrm{N}$ provided the minimum value of $9.46 \mathrm{~g}$ of EPA/MSPA. According to [18], the smaller the quotient obtained more lignified part will be molting and greater survivability in the field. [23], verified that the application of $\mathrm{N}$ in seedlings of thrush, resulted in the best index to the APA/MSPA when composted with the dose of $156 \mathrm{mg} \cdot \mathrm{dm}-3 \mathrm{~N}$, obtained through the quadratic model, being the ratio of around 4.1. [20], observed that the relationship between the height of the aerial and aerial dry mass in the rootstalk of Saputizeiro, gets the biggest result, i.e. the worst result, when not applied any dose of nitrogen, having a maximum value of 7,41 .

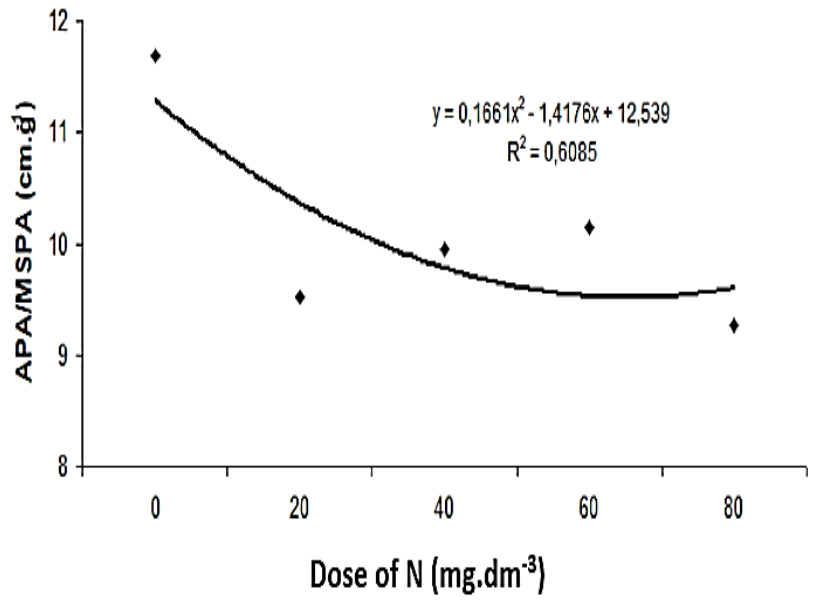

Fig. 10: Relationship of time of the shoot by dry mass offshoots in saplings, Cupuaçu, depending on the nitrogen doses to 42 days after the beginning of weekly fertilization. UFT, Gurupi-TO, 2010. 
the IQD is a balanced formula, including the relationships of the most significant morphological parameters as MST, MSPA, MSR, APA, and DC, having this quality index was developed by [35], working with change Picea glauca e Pinus monficola in 1960.

Regression analysis pointed to be a quadratic response to the application of urea during the cultivation of the Cupuaçu tree seedlings, having a maximum of 0.54 point IQD, the estimated dose 66 mg.dm-3 N (Figure 11). [14], found similar results with nitrogen fertilizer based on ammonium sulfate every 14 and 28 days in seedlings of seven-Peel. [23], reported a quadratic effect of nitrogen dose on seedlings of thrush grown in red-yellow argisols, where the addition of $\mathrm{N}$ provided the highest, at $2.1 \mathrm{de} 173 \mathrm{mg} . \mathrm{dm}-3$.

Observing the curvature of the quadratic model of the Dickson quality index, similar to the parameters of APA, DC, MSPA, MSR, and MST, analyzed previously, demonstrating the occurrence values obtained. Segundo [36], the IQD was a good parameter to indicate the quality of seedlings of Trema micrantha, grown in nursery conditions suspended, since the seedlings with highest rates showed higher values of diameter of the collect, dry matter of the shoot, root and total system, and smaller values of the ratio height/diameter of the stem.

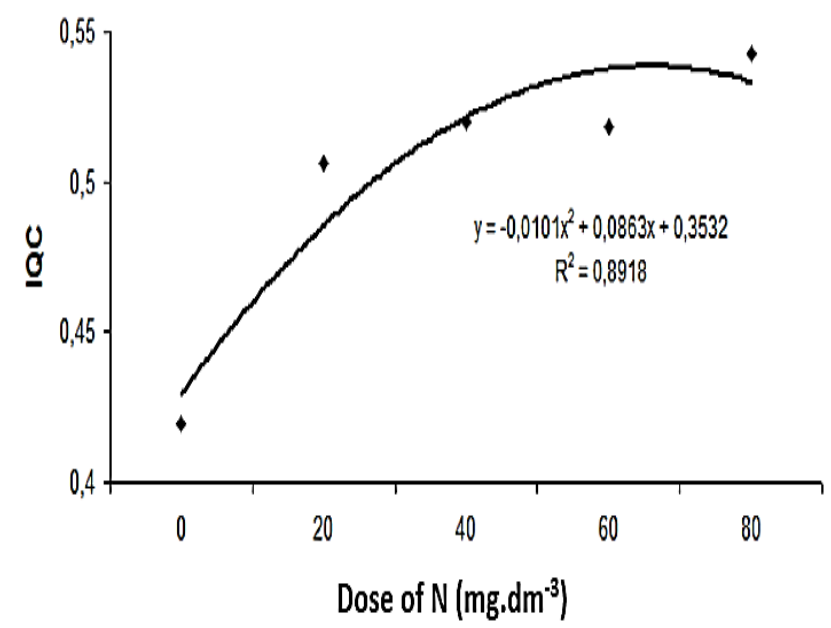

Fig. 11: Dickson quality index (IQD) Cupuaçu tree seedlings, according to the doses of nitrogen to 42 days after the beginning of weekly fertilization. UFT, Gurupi-TO, 2010.

\section{CONCLUSION}

The nitrogen fertilizer with a urea-based solution placed in the substrate of the Cupuaçu tree seedlings greatly affected all morphological parameters evaluated. You can say that the dosages of $\mathrm{N}$, provided height growth of the shoot and stem diameter of seedlings in the course of the evaluation period.

The maximum values in the parameters of shoot height, stem diameter, leaf area, shoot dry mass, root dry mass and total dry mass were obtained for fertilizations between 59.2 and $80 \mathrm{mg}$. The ratio of shoot height by stem diameter and shoot height by dry shoot mass showed that fertilizations with 66 to $80 \mathrm{mg} . \mathrm{dm}-3$ of $\mathrm{N}$ should provide more balanced and healthy Cupuaçu seedlings, which was verified through the IQC which indicated that doses of $66 \mathrm{mg}$.dm-3de cannot promote a better quality standard of Cupuaçu tree seedlings, being that the curve of the quadratic model of the Dickson quality index was similar to the other parameters, so that it can be indicated as a method of analyzing Cupuaçu tree seedlings.

\section{REFERENCES}

[1] LORENZI H, BACHER L, LACERDA M, SARTORI S. (2006) Frutas brasileiras e exóticas cultivadas: (de consumo in natura). Instituto Plantarum de Estudos da Flora LTDA. Nova Odessa -SP.

[2] FERREIRA MGR, CARDENAS FEN, CARVALHO CHS, CARNEIRO AA, Ã O FILHO DAMI, et al. (2001) 12. Desenvolvimento de calos em explante de cupuaçuzeiro (Theobroma grandiflorum Schum.) em função da concentração de auxinas e do meio líquido. Revista Brasileira de Fruticultura. 23(3).

[3] ALVES RM, FILGUEIRAS GC, HOMMA AKO; (2014). Aspectos socioeconômicos do cupuaçuzeiro na Amazônia: do extrativismo a domesticação. Mercado, cadeias produtivas e desenvolvimento rural na Amazônia. Belém, PA:UFRA.

[4] CAVALCANTE PC. Frutas comestíveis da Amazônia. Belém: Edições CEJUP/CNPq/Museu Paraense Emílio Goeldi; (1991).

[5] FACHINELLO JC, HOFFMANN A, NACHTIGAL JC. Propagação de Plantas Frutíferas ;)

[6] VENTURA JA, de M LIMA I, MARTINS MVV, COSTA H. (2017) Impacto e manejo das doenças na propagação das fruteiras. Revista Brasileira de Fruticultura, Jaboticabal, v. 39:173-194.

[7] BARBOSA Z, SOARES I, CRISÓSTOMO LA. Crescimento e absorção de nutrientes por mudas de gravioleira. Revista Brasileira de Fruticultura; (2003).

[8] DA ROS, O C. Uso de substrato compostado na produção de mudas de Eucalyptus dunnii e Cordia trichotoma. Floresta e Ambiente; (2015)

[9] EPSTEIN E, BLOOM AJ. Tart Edição, NUNES MET, editors. Nutrição mineral de plantas: princípios e perspectivas. 2a ; (2004).

[10] SILVA W. Laurentino da et al. Produção de mudas de tamarindo irrigadas com águas salinizadas sob adubação nitrogenada; (2017).

[11] SOUZA HA, PIO R, CHAGAS EA, REIS JMR, RODRIGUES HCA, et al. (2007). DOSES DE NITROGÊNIO E FÓSFORO NA FORMAÇÃO DE MUDAS DE TAMARINDO Biosci J, Uberlândia. 23(1): 59-64.

[12] LIMA MM. Crescimento, composição mineral e sintomas de deficiência de macronutrientes em plantas de Cupuaçuzeiro (theobroma grandiflorum). Dissertação (Mestrado em Agronomia) - Universidade Federal Rural da Amazônia, Belém -; (2002).

[13] CORCIOLI G, BORGES JD, JESUS DE, Paula R. (2014). Sintomas de deficiência nutricional de macronutrientes em mudas de Khaya ivorensis cultivadas em solução nutritiva. Pesquisa Florestal Brasileira. 34(78):159-164

[14] CRUZ FONSECAE, Augusto NOGUEIRADEPAIVAC, Haroldo AMADIOGUERRERO. (2006). Cláudio Renato. Efeito da adubação nitrogenada na produção de mudas de sete cascas (Samanea inopinata (Harms) Ducke). Revista Árvore. 30(4).

[15] SCIVITTARO WB, de OLIVEIRA RP, MORALES CFG, RADMANN EB. (2004). ADUBAÇÃO NITROGENADA NA FORMAÇÃO DE PORTA-ENXERTOS DE LIMOEIRO 'CRAVO' EM TUBETES. Revista Brasileira de Fruticultura, Jaboticabal -. SP.26 (1):131-135.

[16] MELO AS, GOIS MPP, BRITO MEB, VIÉGAS PRA, ARAÚJO FP, et al. (2005) 3. Desenvolvimento de porta-enxertos de umbuzeiro em resposta à adubação com nitrogênio e fósforo. Ciência Rural. 35:2-2.

[17] MENDONCA V, PEDROSA C, FELDBERG NP, ARRUDA NAA, BRITO APF, et al.. Doses de nitrogênio e superfosfato simples no crescimento de mudas de mamoeiro Formosa. Ciência e Agrotecnologia; (2006).

[18] GOMES JM. Parâmetros morfológicos na avaliação da qualidade de mudas de Eucalyptus grandis, produzidos em diferentes tamanhos de tubete e de dosagens de N-P-K. Tese (Doutorado em Ciências 
Florestais) - Universidade Federal de; (2001).

[19] JUNIOR, Nilton Sergio Novack; NICOLETTI, Marcos Felipe; NAVROSKI, Marcio Carlos. Modelagem de variáveis morfológicas em mudas de Eucalyptus dunnii. Floresta, v. 45, n. 4, p. 809-818, 2015.

[20] BRITO CC, MENDONÇA V, MEDEIROS PVQ, TOSTA MS, MEDEIROS LF. (2007). ADUBAÇÃO NITROGENADA EM COBERTURA NA PRODUÇÃO DE PORTAENXERTOS DE SAPOTIZEIRO [Manilkara Zapota (L.). VON ROYEN] ACSA Agropecuária Científica. 3: 08-13.

[21] JÚNIOR SOUZA, de JO, de CARMELLO QA. C.; FORMAS DE ADUBAÇÃO E DOSES DE URÉIA PARA MUDAS CLONAIS DE CACAU CULTIVADAS EM SUBSTRATO. Revista Brasileira Ciência do Solo; (2008).

[22] VANDERLEI, B. P. Crescimento e qualidade de mudas de Acacia mangium Willd. Em resposta À adubação nitrogenada. Dissertação (mestrado), Universidade Federal do Ceará, 2018.

[23] MARQUES VB, PAIVA HN, GOMES JM, NEVES JCL. Efeitos de fontes e doses de nitrogênio no crescimento de mudas de sabiá (Mimosa caesalpiniaefolia Benth.). Scientia forestalis; (2006).

[24] CARNEIRO JG. A Produção e controle de qualidade de mudas florestais. Curitiba - PR, Universidade Federal do Parana; (1995).

[25] MENEGATTI, Renata Diane et al. Formação de mudas de guatambu em substrato com hidrogel e fertilizante de liberação controlada. Revista Espacios, v. 38, n. 22, p. 35-47, 2017.

[26] STURION JA, ANTUNES BMA; (2000). Produção de mudas de espécies florestais. In: GALVÃO, A.P.M. Reflorestamento de propriedades rurais para fins produtivos e ambientais. Colombo: EmbrapaFlorestas.

[27] PAGLIARINI, Maximiliano Kawahata et al. NÍVEIS DE SOMBREAMENTO NO DESENVOLVIMENTO DE MUDAS DE Hymenaea courbaril var. Stilbocarpa. Cultura Agronômica: (Revista de Ciências Agronômicas, v. 26, n. 3, p. 330-346, 2017.).

[28] SAliSBURY, F.B.; ROSS, C.W. Plant Physiology. Belmont: Wadsworth, 1992. 682 p. ROSS CW; (1991).

[29] SCHWERZ, Felipe et al. Avaliação do efeito de doses e fontes de nitrogênio sobre variáveis morfológicas, interceptação de radiação e produtividade do girassol. Rev. Ceres, Viçosa, v. 63, n. 3, p. 380-386, June 2016. Available from <http://www.scielo.br/scielo.php?script=sci_arttext\&pid=S003473 7X2016000300380\&lng=en\&nrm=iso >.Accesson 06 June 2019. h ttp://dx.doi.org/10.1590/0034-737X201663030015.

[30] MARQUES ARF. Produção e qualidade de mudas de Psidium cattleianum Var. cattleianum Sabine (Myrtaceae) em diferentes substratos. Acta Biológica Catarinense; (2018).

[31] ALMEIDA EV, NATALE W, de M PRADO R, BARBOSA JC; (2006). Adubação nitrogenada e potássica no desenvolvi- mento de mudas de maracujazeiro. Ciência Rural. vol. 36. Santa.

[32] LOPES PSN, de MELO B, NETO CUNHA, da FR, RAMOS JD, et al.. Adubação nitrogenada e substratos no crescimento de mudas de maracujazeiro amarelo em tubetes. Revista Universidade Alfenas; (1999).

[33] DECARLOS NETO, A.; SIQUEIRA, D. L. de; PERREIRA, P. R. G.; ALVAREZ, V. H. Crescimento de porta-enxertos de citros em tubetes influenciados por doses de N. Revista Brasileira de Fruticultura, Jaboticabal, v. 24, n. 1, p. 199-203, 2002.

[34] De C BERNARDI AC. (2000). Desenvolvimento de mudas de citros cultivadas em vaso em resposta à adubação NPK. Scientia Agricola. 57:4-733.

[35] DICKSON, A.; LEAF, A. L.; HOSNER, J. F. Quality appraisal of white spruce and white pine seedling stock in nurseries. Forestry Chronicle, v. 36, p. 10-13, 1960.

[36] FONSECA EP, VALERI SV, MIGLIORANZA E, FONSECA NAN, COUTO L. (2002). Padrão de qualidade de mudas de Trema micrantha (L.) Blume, produzidas sob diferentes períodos de sombreamento. Revista Árvore, Viçosa.26:4-515. 